\title{
IMPLEMENTATION OF THE COMPLIANCE SYSTEM IN THE ACTIVITIES OF AGRICULTURAL ENTERPRISES IN UKRAINE: PREREQUISITES AND MAIN ASPECTS
}

\author{
Maryna Dubinina, Iryna Ksonzhyk, *Svitlana Syrtseva, Yuliia Cheban, Olha Luhova, Tetiana Pisochenko \\ Mykolayiv National Agrarian University, Ukraine \\ *Corresponding author's email: syrtseva@ukr.net
}

\begin{abstract}
The article defines the prerequisites and main aspects of implementation of the compliance system in activities of agricultural enterprises in Ukraine. It has been established that the compliance system for Ukrainian agricultural enterprises is completely new, and there are practically no procedures for its formation and functioning. Using SWOT analysis matrix, strengths and weaknesses, opportunities and threats of the compliance system for Ukrainian agricultural enterprises have been identified. It has been established that the agricultural business is able to ensure the implementation and operation of the compliance system, which is focused on international compliance values. An algorithm for introducing a compliance system into the activities of agricultural enterprises has been proposed. Its implementation and observance will allow agricultural enterprises to minimize compliance risks, ensure their financial stability and innovative development, increase trust of customers, partners and investors to be competitive both in the domestic market and external one. It has been determined that compliance risk management is a cyclical process, whose main goal should be to minimize the identified risks using the development and implementation of appropriate control procedures and measures. In order to minimize compliance risks arising in the process of relations between agricultural enterprises and counterparties, an organizational model of their management has been proposed. The application of the methodological approaches presented in the model will allow agricultural enterprises to establish working relationships with counterparties, including foreign ones, and in the future to attract foreign capital and investment in their activities.
\end{abstract}

Key words: compliance system, agricultural enterprises, compliance policy, compliance risk.

\section{Introduction}

In the context of integration into the international space and full-fledged membership of Ukraine in the World Trade Organization, the issues of access to the international market for agricultural products, the quality of which must meet the requirements of current legislation, international standards, export competition in agricultural and food trade, are quite acute. In addition, for the effective development of entrepreneurial activity at the international level, Ukrainian agricultural enterprises need to constantly confirm that their activities comply with the established ethical and business standards of doing business in the vector of combating corruption and fraud and managing the risks of the possibility of introducing international sanctions. However, the influence of external factors (political, economic instability, COVID-19) and internal (violation of legislation, business ethics, conflict of interests) significantly increase the level of risky processes in the functioning of agricultural enterprises. All this requires the management of agricultural enterprises to develop mechanisms that minimize the likelihood of not only financial losses, but also loss of confidence on the part of customers in the domestic and international markets, loss of finding international business partners and investors. A comprehensive solution to these tasks can ensure the implementation of a compliance system.

The theoretical and methodological aspects of compliance have been studied in the works of a significant number of scientists, in particular (Adelina et al., 2020; Bilal \& Baig, 2019; Birindelli \& Ferretti, 2008; Bovsh \& Kulyk, 2020; Fedulova \& Piatnytska, 2020; Foorthuis \& Bos, 2011; Kalinichenko, 2014; Kobielieva, 2019; Kozhina, 2019; Lavrenko, 2020; Ludwick, 2006; Meissner, 2018; Vanni, 2017; Vnukova, 2018; Voloshenko, 2014; Yudina, 2018) et al. Their researches are aimed at solving important problems of the development of the compliance system in industrial enterprises and various sectors of the economy, in particular the banking and insurance spheres. At the same time, it should be noted that the issues related to the definition of the basic prerequisites, the development and substantiation of theoretical and methodological approaches to the implementation and formation of a compliance system in the activities of agricultural enterprises in Ukraine require further development.

The goal of scientific articles is to determine the prerequisites and main aspects to develop theoretical and methodological foundations, to substantiate methodological recommendations for the implementation of the compliance system in the activities of agricultural enterprises in Ukraine.

\section{Materials and Methods}

The methodological basis of scientific research is the theory of systems, the theory of the development of economic systems, the theory of risk management, the theory of decision-making. When writing the article, general scientific and special methods were 
used: abstract-logical (cognition of the essence, prerequisites and features of the implementation of the compliance system in the activities of agricultural enterprises, the formation of conclusions), system analysis (presentation and description of the algorithm of actions for the implementation of the compliance system in the activities of agricultural enterprises), method of SWOT analysis matrix (identification of strengths and weaknesses, as well as opportunities and threats arising in the process of introducing the compliance system into the activities of agricultural enterprises), graphical (design of the described processes using logical algorithms, organizational models).

\section{Results and Discussions}

"Compliance" translated from English means accordance, conformity, agreement. Compliance is an institution of the internal control and corporate ideology system, which, using a system of regulations and a set of control mechanisms, forms the company's ability to comply with established norms, standards, rules and procedures, and also necessarily takes into account the risks accompanying its activities, and with the help of a set of measures eliminates their adverse consequences, as a result of which - ensures the sustainable development of the enterprise.

For agricultural enterprises, in particular Ukrainian ones, the compliance system is quite new, and there is practically no description of the procedures for its formation and functioning in this area. This is confirmed by a survey devoted to the priorities of the development of the compliance function in Ukraine, the countries of the Commonwealth of Independent States (CIS) and neighboring countries, conducted by KPMG (auditing firm) in Ukraine.

Thus, according to the research, today the oil and gas industry remains an industry where a separate compliance function began to form earlier than anywhere else (Figure 1). This sector is the leader in terms of the number of respondents who have had compliance functions for more than 10 years. The youngest compliance function according to the research results are in companies operating in the field of innovation and technology. As for the enterprises of the agricultural sector of the economy, none of the surveyed respondents used the functions and tools of the compliance system.

In the period 2017-2019, Ukrainian producers were in the top three among the world exporters of agricultural products to the European Union. This fact demonstrates the importance and necessity of their activities in accordance with international compliance values.

We have identified a number of advantages and benefits from the implementation of the compliance system in the activities of agricultural enterprises (Table 1). However, there are weaknesses and threats that hinder the implementation of the compliance system, including: lack of appropriate legislative and regulatory support, insufficient number of specialists, incurring additional costs on the part of the enterprise.

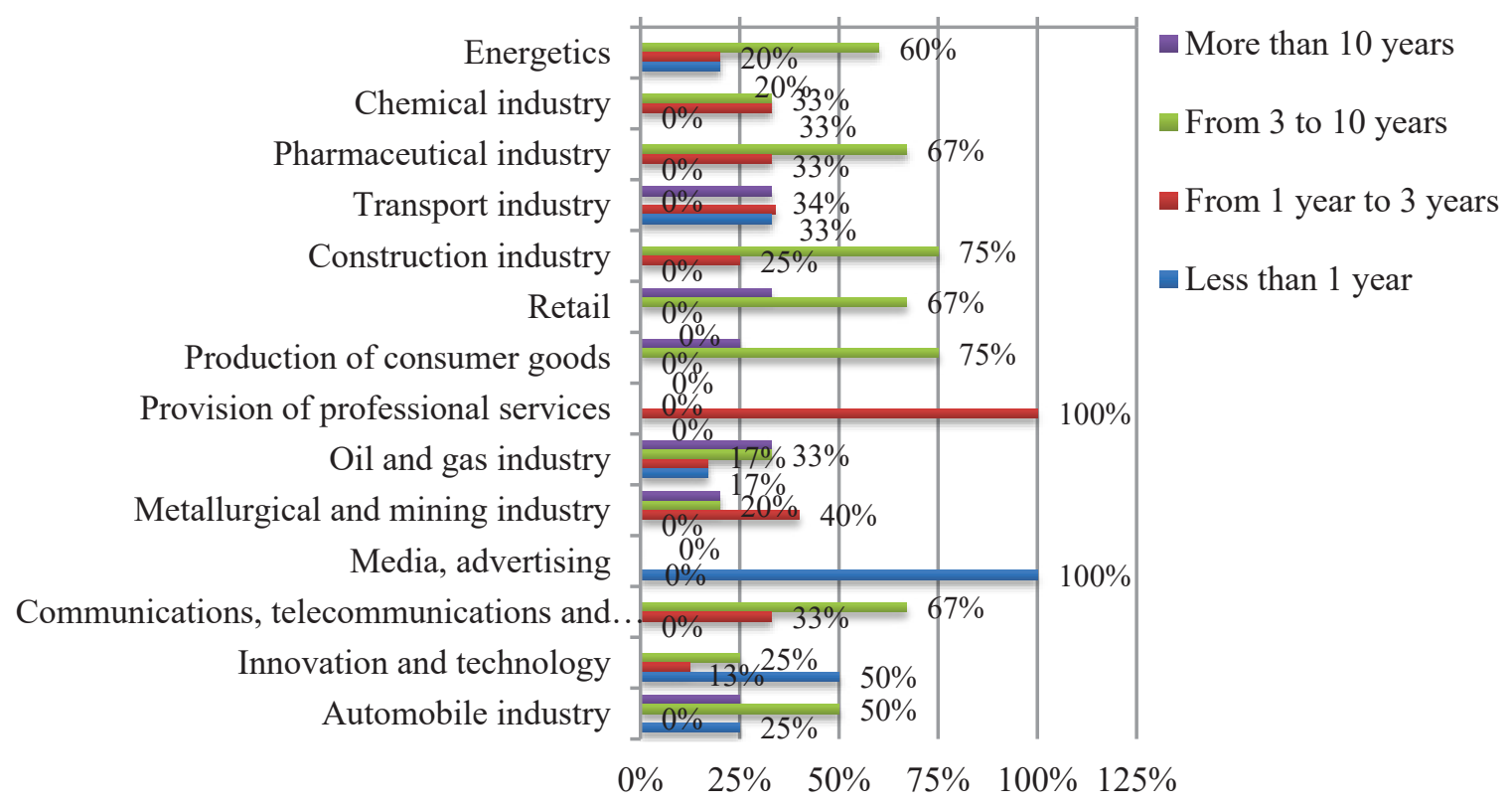

Figure 1. Implementation of the compliance system in the sectors of the economy of the CIS and Post-Soviet Countries, 2020.

Source: (data of KPMG's survey in Ukraine "Compliance in the CIS and Post-Soviet Countries: Current Issues and Trends, 2020"). 


\section{SWOT analysis matrix of the implementation of the compliance system in the activities of agricultural} enterprises in Ukraine

\begin{tabular}{|c|c|}
\hline Stre & Weaknesses \\
\hline $\begin{array}{l}\text { 1. Effective risk management. } \\
\text { 2. Protection of business from theft, fraud. } \\
\text { 3. Minimization of risks of loss of assets, image. } \\
\text { 4. Increasing the level of corporate culture and social } \\
\text { responsibility of agricultural enterprises. } \\
\text { 5. Increasing consumer confidence in agricultural products } \\
\text { in the domestic and external markets. } \\
\text { 6. Increasing the profitability and financial stability of the } \\
\text { enterprise. }\end{array}$ & $\begin{array}{l}\text { 1. Lack of domestic regulatory framework on compliance } \\
\text { issues (except for the banking sector). } \\
\text { 2. Insufficient practice of implementation of compliance } \\
\text { and, accordingly, dissemination of information about } \\
\text { such positive results. } \\
\text { 3. Insufficient number of compliance specialists. } \\
\text { 4. Additional expenses of the company for the } \\
\text { maintenance and operation of the compliance service. }\end{array}$ \\
\hline Oppor & ats \\
\hline $\begin{array}{l}\text { 1. Increase in production volumes of high technology } \\
\text { competitive agricultural products. } \\
\text { 2. Attracting international investments. } \\
\text { 3. Simplification of entering international markets. } \\
\text { 4. Growth of economic potential. } \\
\text { 5. Obtaining certain tax incentives. } \\
\text { 6. Improving relations with contractors. }\end{array}$ & $\begin{array}{l}\text { 1. Disinterest of the management in ensuring the } \\
\text { functioning of the compliance system at the } \\
\text { enterprise. } \\
\text { 2. Resistance from the employees of the enterprise in the } \\
\text { implementation of the compliance system. } \\
\text { 3. Lack of verification of the effectiveness of the } \\
\text { compliance service. }\end{array}$ \\
\hline
\end{tabular}

Source: prepared by the authors.

Analysis of opportunities and threats allows us to conclude that, despite the weaknesses and existing difficulties, the agricultural business is undoubtedly an industry that is focused on international compliance values and is able to ensure the implementation and functioning of the compliance system.

The compliance culture must successfully reinforce itself in enterprises, and for this purpose, it is necessary to persuade senior management that compliance is not a cost that should be minimized (Vanni, 2017).

According to Herasymchuk, 2019, for the effectiveness of the compliance system at the enterprise, it should regulate in detail the following main issues: identification of persons responsible for the operation of the compliance system, effective management of identified risks and implementation of measures in case of violations, determination of ways to implement them.

In our opinion, it is advisable to use the proposed algorithm of actions in order to ensure the implementation of an effective compliance system in the activities of agricultural enterprises (Figure 2).

The introduction of the compliance system should be started with the formation of the compliance policy of the agricultural enterprise. Compliance policy

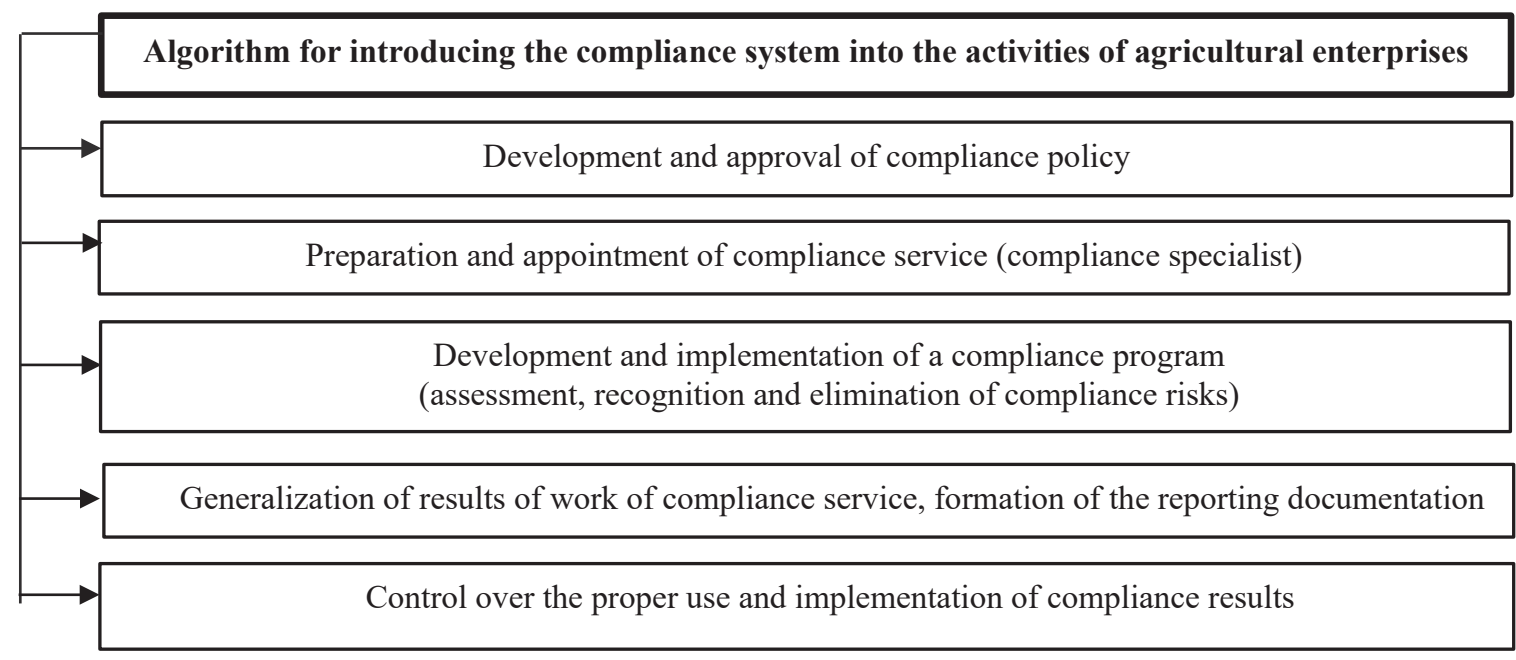

Figure 2. Algorithm for introducing the compliance system into the activities of agricultural enterprises (author's vision). 
defines the purpose, objectives of compliance at the enterprise, principles and basic processes.

The objectives of the compliance policy are: creation of an effective compliance risk management system; bringing to the attention of the company's employees, as well as third parties, the basic principles of compliance; prevention of a conflict of interests and the conditions for its occurrence, as well as the possibility of committing crimes and other illegal actions; supporting corporate values and rules, striving to improve corporate culture; ensuring compliance with the principles of open and honest business conduct; ensuring transparency of activities for shareholders, third parties and regulatory bodies; maintaining the business reputation of the enterprise at the appropriate level; achievement of the set strategic goals by the enterprise.

The main task of the compliance policy should be to ensure the formation of an effective system of measures aimed at reducing risks in all areas of the agricultural enterprise, compliance with legislative norms, internal regulations, corporate culture and social responsibility rules.

The issue of ensuring the compliance system at the enterprise should concern all its employees and is a component of its corporate environment. Therefore, the next step should be the appointment and inclusion of the compliance service in its organizational structure (Kobielieva, 2019):

- on a centralized basis, that is, to create an independent unit that will be fully responsible for the company's compliance activities or appoint a compliance specialist;

- on a decentralized basis, that is, to distribute and delegate compliance functions, for example, between the legal department, audit service, enterprise security service, risk management unit.

The compliance service, as a structural unit of an agricultural enterprise, should be independent of the business goals of the enterprise and must cooperate with other structural units. The duties of the employees of the compliance service or the compliance specialist should be reflected in the developed and approved job descriptions and accounting policies of the enterprise in the context of the activities areas (operational, financial, investment) (Lavrenko, 2020). Compliance service employees must be able to identify, assess, analyze, control and respond positively to compliance risks. Thus, compliance risks are understood as potential or real risks of regulatory sanctions, financial losses, reputational losses that arise as a result of noncompliance with legislation, provisions of internal documents (policies, procedures, regulations, rules), fair competition standards, situations of conflict of interest, non-compliance with requirements of corporate ethics.
The development and implementation of a compliance program at the enterprise is the next step. The main goal of the program may be to ensure effective measures to identify and control risk areas of activity; identification, assessment and minimization of compliance risks. It is minimization that is the goal of managing them, not optimization, because they are characterized by a negative impact on the activities of the enterprise (Vnukova, 2018).

Compliance risk management as an element of the enterprise risk management system is a cyclical process, which includes: identification of compliance risks; assessment of compliance risks; planning of measures of protection against compliance risks; implementation of measures of protection against compliance risks; monitoring and control. That is, it is necessary to manage risks through the implementation of compliance control of business processes (to minimize the likelihood and mitigate the consequences of negative situations, to organize highquality feedback with market participants) (Bovsh \& Kulyk, 2020).

The information base for identifying compliance risks of agricultural enterprises is the process of the agricultural enterprise activity as a whole, expert conclusions of the internal control system divisions, independent audit reports, the results of inspections by regulatory authorities, court decisions, complaints and claims from counterparties, etc.

In our opinion, a prerequisite for the success of the identification of compliance risks in the activities of agricultural enterprises should be the systematic collection, analysis and processing of information from various sources (testing, check lists, questionnaires, appeals in communication channels, the results of extraordinary inspections, etc.). The above will also allow agricultural enterprises to timely and fully identify existing and potential risks, the sources of their occurrence, the consequences of their impact on the activities of the enterprise.

Risks assessment involves determining the degree of probability of their occurrence and possible negative consequences. The most convenient way to assess compliance risks for agricultural enterprises is to assess risks using the method of qualitative assessments and their further minimization. In practice, to carry out such an assessment, it is possible to compile a risk matrix with an appropriate scale of points, developed for each enterprise independently.

So, the main goal of the compliance risk management process should be to minimize the identified risks through the development and implementation of appropriate control procedures and measures (Birindelli \& Ferretti, 2008).

Monitoring and control should be the next step in agricultural compliance risk management. Monitoring 
Compliance risks management model arising in the process of interaction of agricultural enterprises with counterparties

I5

\section{Checking counterparties}

Objective: 1) compliance with the requirements of the tax authorities (due diligence); 2) identification of cases of conflict of interest; 3) compliance with the requirements of national and foreign anti-corruption legislation; 4) preventing fraud and corruption

Responsible for control:

- on a centralized basis, a compliance service or a compliance specialist is responsible for the control,

- on a decentralized basis, distribute and delegate the functions of checking counterparties between the legal department, security service, department responsible for planning the conclusion of contracts with counterparties, accounting department, and risk management department.

Inspection frequency:

- in case of interaction with new counterparties - obligatory at the initial conclusion of the contract;

-in case of interaction with permanent counterparties - at the conclusion of the contract; at least once a year.

\begin{tabular}{|c|}
\hline 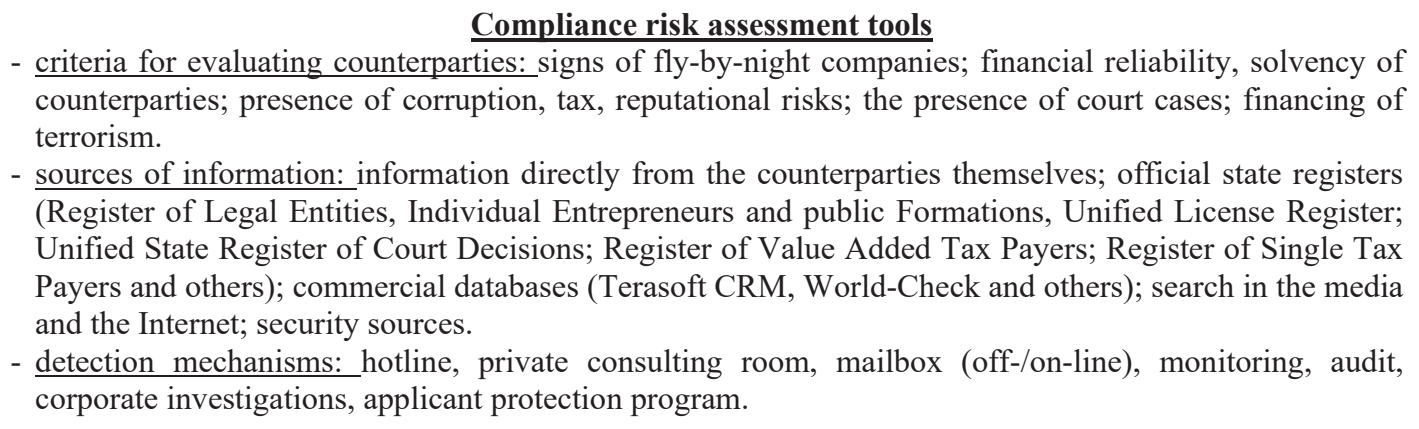 \\
\hline
\end{tabular}
corporate investigations, applicant protection program.

\footnotetext{
Directions of minimization of compliance risks associated with counterparties

1. Inclusion of anti-corruption clauses and provisions with the right to audit in contracts and agreements with contractors.

2. Monitoring of risky transactions and agreements with counterparties.

3. Verification and approval of payments made to the counterparty.

4. Development and implementation into business practice of the provisions of the Supplier Code of Conduct, which should include such ethical requirements as commercial virtue, fair competition, control of international trade, conflicts of interest, confidentiality and data protection, fair marketing practices, standards for clinical trials, environmental protection rules.

5. Training of counterparties on compliance and ethics issues.

6. Creation of a base of counterparties that have compliance risks.
}

\section{II}

\section{Monitoring and control}

1. Current testing of risky transactions in terms of their content, correctness of reflection in the accounting, as well as the availability of all the necessary supporting documents.

2. Working with the base of counterparties that have compliance risks.

3. Preparation of reports on the assessment of compliance risks.

4. Control over the proper use and implementation of the results of risk management.

Figure 3. Organizational model of management of compliance risks of agricultural enterprises arising in the process of interaction with counterparties.

contributes to a better understanding of the compliance risk management process, determination of the current level of risk, and its propensity to change. An important aspect of this process is continuous monitoring of the quantitative measurement of compliance risks and trend analysis (Yudina, 2018).
Ludwick, 2006 proposes to create a reporting system on the basis of which the compliance service can identify, track and communicate the risks it faces.

In order to identify and minimize compliance risks arising in the process of interaction of agricultural enterprises with counterparties, we 
proposed an organizational model for managing such risks (Figure 3).

The proposed model for managing compliance risks that arise in the process of relationships with counterparties will allow agricultural enterprises of Ukraine to minimize risks, establish reliable and effective working relationships with foreign counterparties, and in the future, attract foreign capital and investments into their activities for its own development.

\section{Conclusions}

1. The introduction of the compliance system, as an institution of the internal control and corporate ideology system, into the activities of agricultural enterprises in Ukraine will contribute to:

- ensuring financial stability and innovative development of enterprises;

- improving reputation, increasing trust from customers, partners and investors, especially foreign ones;

- protection against threats and risks associated with violation of approved norms and standards;

- increasing the level of social responsibility of enterprises.

2. The construction of a SWOT analysis matrix for the implementation of the compliance system in the activities of agricultural enterprises in Ukraine made it possible to identify its strengths and identify opportunities. Weaknesses and existing threats are not an obstacle for the agricultural business to focus on international compliance values, since this is an industry that is able to ensure the implementation and functioning of the compliance system.

3. To implement the compliance system in the activities of agricultural enterprises, it is advisable to use a certain algorithm, which provides for the development and implementation of a compliance program, preparation and appointment of a compliance service, management of compliance risks, generation of reporting documentation, control over the proper use and implementation of compliance results.

4. Compliance risk management, as an element of the enterprise risk management system, is a cyclical process that involves the identification and assessment of compliance risks, planning and implementation of measures of protection against compliance risks, monitoring and control. The main goal of the compliance risk management process should be to minimize the identified risks through the development and implementation of appropriate control procedures and activities.

5. Using the proposed model for managing compliance risks that arise in the process of relationships with counterparties will allow agricultural enterprises of Ukraine to minimize these risks. The latter can only be a positive prerequisite for further cooperation of agricultural enterprises with foreign and domestic partners and the development of their activities.

\section{References}

Adelina, Y.E., Trilaksono, T., \& Rohi-Mone, R. (2020). Do corporate and Sharia compliance governance affect the enterprise risk management implementation? Jurnal Keuangan dan Perbankan, 24(1), 1-19. DOI: 10.26905/jkdp.v24i1.3768.

Bilal, A.R., \& Baig, M.M.A. (2019). Transformation of agriculture risk management: The new horizon of regulatory compliance in farm credits. Agricultural Finance Review, 79 (1), 136-155. DOI: 10.1108/AFR-05-2018-0038.

Birindelli, G., \& Ferretti, P. (2008). Compliance risk in Italian banks: the results of a survey. Journal of Financial Regulation and Compliance, 16 (4), 335-351.

Bovsh, L., \& Kulyk, M. (2020). Komplaiens biznes-protsesiv hoteliu v umovakh pandemii (Compliance of hotel business processes under pandemic conditions). HERALD of Kyiv National University of Trade and Economics, 5, 58-67. DOI: 10.31617/visnik.knute.2020(133)05. (in Ukrainian).

Doslidzhennia audytorskoi kompanii KPMG v Ukraini "Komplaiens v SND i blyzhnomu zarubizhzhi: aktualni zavdannia ta tendentsii" (Survey of KPMG in Ukraine Compliance in the CIS and Post-Soviet Countries: Current Issues and Trends). 2020. Retrieved March 4, 2021, from https://assets.kpmg/content/dam/kpmg/ ua/pdf/2020/07/Compliance-report.pdf. (in Ukrainian).

Fedulova, I., \& Piatnytska, G. (2020). Syhnifikatsiia ryzyk-menedzhmentu, antykryzovoho upravlinnia ta komplaiensu v upravlinni finansovoiu bezpekoiu pidpryiemstva (Signification of risk management, crisis management and compliance in the financial safety management of an enterprise). Ekonomika ta derzhava, 8, 26-34. DOI: 10.32702/2306-6806.2020.8.26. (in Ukrainian).

Foorthuis, R., \& Bos, R. (2011). A framework for organizational compliance management tactics. Lecture Notes in Business Information Processing,83, 259-268.

Herasymchuk, H. (2019). Komplaiens yak konkurentna perevaha vashoho biznesu (Compliance as a competitive advantage of your business). Retrieved March 4, 2021, from https://businessviews.com.ua/ru/business/id/ scho-take-komplajens-1965/\#. (in Ukrainian). 
Kalinichenko, L.L. (2014). Teoretychni aspekty funktsionuvannia komplaiensu u vitchyznianykh bankakh (Theoretical aspects of compliance functioning in Ukrainian banks). Scientific Bulletin of Kherson State University. Series “Economic Sciences”, 6, 242-245. (in Ukrainian).

Kobielieva, T.O. (2019). Komplajens-bezpeka promyslovogho pidpryjemstva: teorija ta metody (Compliancesafety of industrial enterprise: theory and methods). Kharkiv: OOO "Planeta-prynt". (in Ukrainian).

Kozhina, V.O. (2019). Komplaens-kontrol' v deyatel'nosti organizacij (Compliance control in the organization activity). Economics: Yesterday, Today and Tomorrow, 9, 166-172. DOI: 10.34670/AR.2020.93.11.019. (in Russian).

Lavrenko, E.A. (2020). Vnedrenie komplaensa v sistemu upravleniya predpriyatiem (Implementation of compliance in the enterprise management system). Humanitarian Scientific Bulletin, 6, 50-53. (in Russian).

Ludwick, K. (2006). Tackling risk-based compliance. Journal of Investment Compliance, 7(4), 61-64. DOI: $10.1108 / 15285810610719961$.

Meissner, M.H. (2018). Accountability of senior compliance management for compliance failures in a credit institution. Journal of Financial Crime, 25 (1), 131-139. DOI: 10.1108/JFC-11-2016-0074.

Vanni, D. (2017). The role of compliance in Italian banking system. Journal of Financial Crime, 24 (1), pp. 143-147. DOI: $10.1108 / \mathrm{JFC}-04-2016-0025$.

Vnukova, N.N. (2018). Upravlinnia ryzykamy finansovykh ustanov u sferi finansovoho monitorynhu (Financial institutions risks management in the field of financial monitoring). Scientific Notes of Ostroh Academy National University, "Economics" series, 8(36), 64-68. DOI: 10.25264/2311-5149-2018-8(36)-64-68. (in Ukrainian).

Voloshenko, A.V. (2014). Komplaiens-praktyka yak preventyvnyi metod borotby z koruptsiieiu (Compliance practice as a preventive method against corruption). Actual problems of economics, 7(157), 405-413.

Yudina, Yu. (2018). Upravlenie komplaens-riskom v deyatel'nosti hozyajstvuyushchego sub"ekta (Compliance risk management in the activities of an economic entity). Modern research and development, 12 (29), 1101-1104. (in Russian). 